\title{
耳下腺深葉脂肪腫の一症例
}

\author{
中島徹・上杉 康夫・永田 誠治 \\ 山本 祐三・牧本一男・高橋 宏明 \\ 福瀬 信也*
}

\section{Lipoma in the Deep Lobe of the Parotid Gland;}

\section{A Case Report}

\author{
Toru Nakajima, Yasuo Uesugi, Seiji Nagata, \\ Yuzo Yamamoto, Kazuo Makimoto and Hiroaki Takahashi \\ (Osaka Medical College) \\ Shinya Fukuse \\ (Saiseikai Suita Hospital)
}

60 -year-old male had a tumor which originated in the deep lobe of the parotid gland and extended to the parapharyngeal space. CT-sialography revealed tumor extension to the parapharyngeal space with clear imaging. The CT number of this tumor was lower $(-104$ to -128$)$ than that of lipoma tissue $(-80$ to -90$)$.

Ga-scintigraphy showed RI accumulation, probably because of the sialography performed 35 days before scintigraphy.

Under general anesthesia, the patient was operated on. The tumor was a parotid tumor with a dumbell-like shape.

Key words: parotid gland, lipoma, case report

\section{はじめに}

耳下腺の良性腫瘍は pleomorphic adenoma, monomorphic adenoma など上皮性腫煌 がその多くを占め, 非上皮性腫瘍は比較的稀で ある。我々は耳下腺深葉に発生して副咽頭間隙 へ進展していた脂肪腫を経験したので, 若干の 文献的考察を加え報告する.

$$
\text { 症例 }
$$

\section{主訴 : 右耳下腺部腫瘤}

現病歴：昭和60年春頃より右耳下腺部に無痛 性の腫溜に気付くも放置, 同年11月頃より次第 に増大傾向を認めたため, 炤和 61 年 1 月 23 日済 生会吹田病院耳鼻科を受診した。

既往歴, 家族歴：特記すべきことなし.

局所所見 : 右耳下腺部に, 弾性軟, 表面平泻 で境界不明膫な $45 \times 40 \mathrm{~mm}$ の腫瘤を触知した。顔 面神経麻㾝はなく, 压痛, 皮䖉との癒着屯認め 
ないが，深部に対する可動性は不良で，耳下腺 深葉の腫瘍が疑われた。

検査所見：同年 1 月 27 日 Stenon 管よりリ ピオドール約 1.5 ccを注入, CT-sialography を行った，耳下腺中央から，副咽頭間隙に拡が る境界明膫な均一な low density area を認 めた（図 1 ）。同部の C T值を求めてみると, -104〜 -108と非常な低值を示した. 同時に撮 影した sialography における側面断層像では, 耳下腺後上方に境界明瞭な腫瘍像を認めた（図 2 ). Tc による唾液腺 scintigraphy では右 耳下腺部に欠損像を認め, 造影剂の影響を避け るため35日間の間隔をおいて Ga-scintigraphy を実施したところ右耳下腺に相当する部 分に陽性所見を得た（図 3 ). 悪性の耳下腺腫 瘍の可能性むありとして，同年 3 月 7 日大阪医 科大学耳鼻科に紹介を受けた。耳下腺腫焬の補

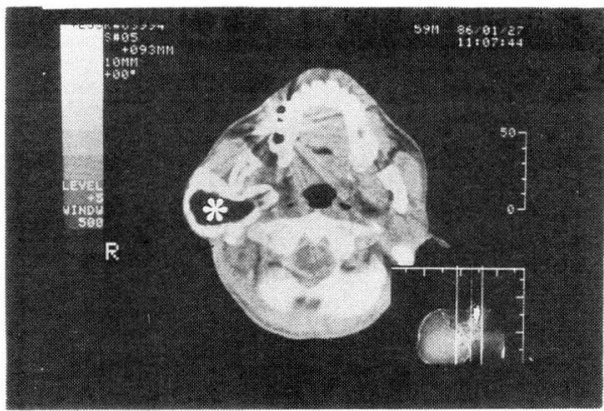

図 ICT-sialogyaphy ＊印は低いCT值を示す腫煬部位を示す。

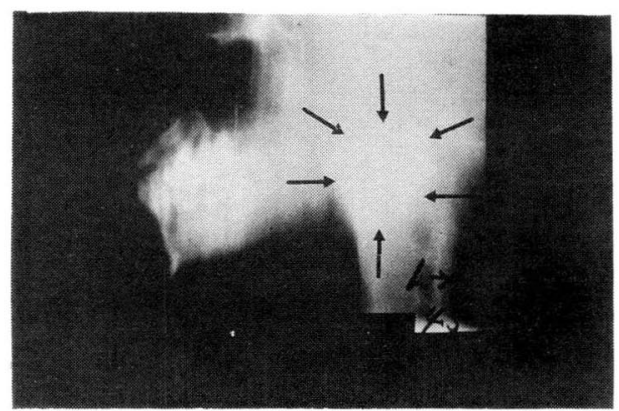

図 2 sialography（側面断首） 矢印は腫煌部の陰影増強を示す。
助診断法の一つに Xeroradiography がある が, 我々は, 被爆線量が Xeroradiography と比較し半分以下に軽減された KIP-electroradiography を行っている.この方式による sialography では耳下腺内側上方に欠損像を 認める屯導管の断裂，漏洩などは認めず（図 4 )，3月11日実施した echography では，

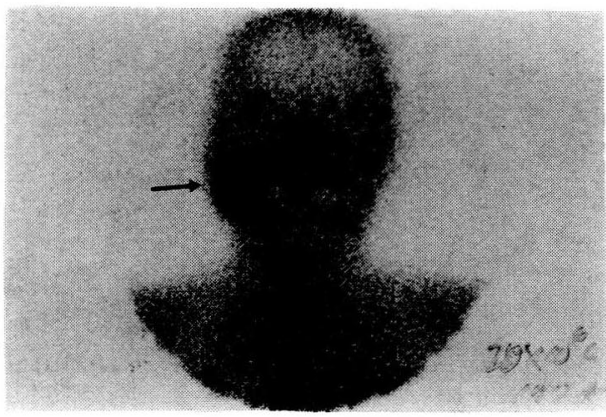

図 3 Ga-scintigraphy 右耳下腺部に $\mathrm{Ga}$ の集積がみられる.

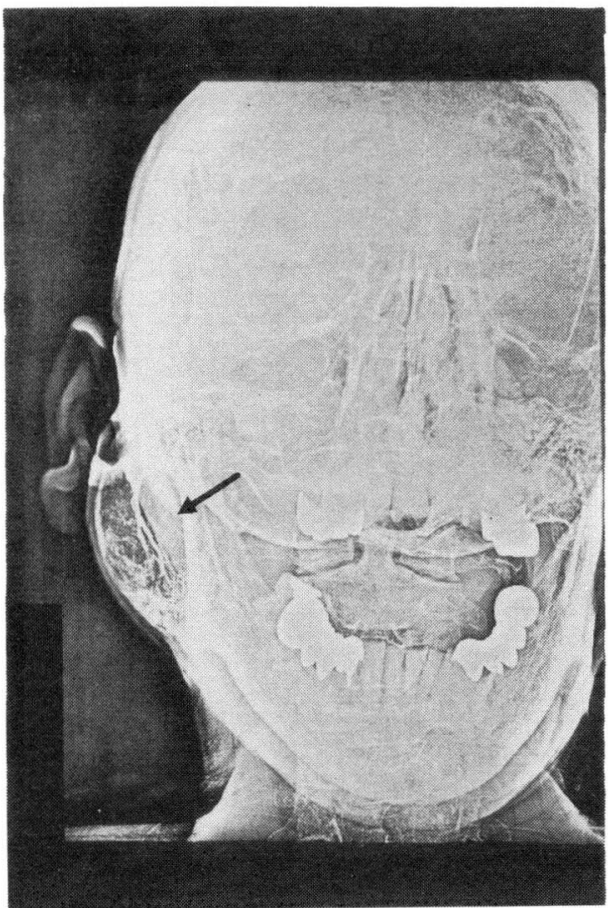

図 4 sialography (KIP-electroradiography) 浅葉の内側上方に腺影の欠損がみられる。 
境界不明瞭, 内部エコー不均一で mixed pat tern を示す像を得た（図 5 ). 全身所見, 理 学検査, 血液学的検査に異常所見は認められな かった.

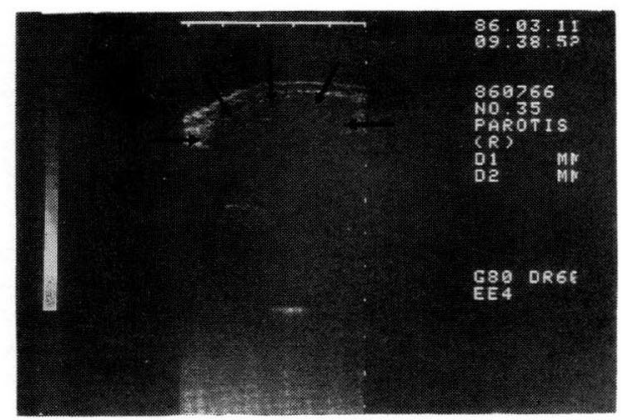

図 5 echography

mixed pattern が示される. 矢印は腫煌の表面 境界を示す．深部との境界は不明睹である.

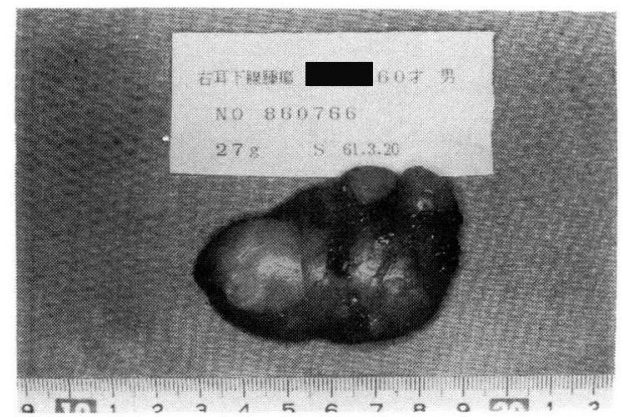

図 6 摘出標本 亜鈴型に近い形を示す。

図 7 病理組織像 $(\mathrm{HE}$ E染色 $\times 400)$ 胞体内は脂肪で充満する成熟した脂肪細胞のみで 構成されている.
治療経過および手術所見：悪性，良性，両者 の可能性を考元，手術目的で同年 3 月 18 日大阪 医科大学耳鼻咽喉科に入院となった。 3 月20日 全身麻酔下に右外頸動脈結禁術，右耳下腺腫瑒 摘出術を施行した，耳下腺浅葉は腫瘍によって 前下方に圧排され, 顔面神経は腫焬により外下 方に，圧排され偏位していた。術中迅速病理 診断にて lipoma の診断を得たため, 顔面神 経, 耳下腺浅葉から腫湯を剝離し, 深葉の腫瘍 を摘出した，摘出した腫瘍は亜鈴型に近い形を 示し弾性軟, 表面平滑で黄白色の色調を呈して いた。重量は27 $\mathrm{g}$, 割面も黄白色充実性で脂肪 様外観を呈していた（図 6 ). 病理組織学的に は, 腫瘍は薄い䋐維性被膜におおおれており， 均一な成熟した脂肪細胞のみで構成される脂肪 腫之の診断を得た（図 7 ). 術後, 一過性の顔 面神経麻痵を生じたが, steroid 剂, 神経賦活 剂の投与にて約 2 ケ月で完全に回復した.

\section{考案}

脂肪腫は, 脂肪組織あるいは繊維組織などの 軟部組織を発生母地とする間葉系腫瘍に属する 良性腫瘍であり, 全身の各種臟器に発生し, そ の頻度む決して少なくはない，耳鼻咽喉科領域 では喉頭 ${ }^{1)}$, 咽後部 ${ }^{2)}$, 耳下腺 ${ }^{34)}$ 亿発生した報 告例はあるが比較的稀である. 耳下腺脂肪腫に ついて文献的にその頻度を検索すると Baker ${ }^{5)}$ らは文献的に耳下腺腫啺 6101 例をまとめ, その 内76例 (1.2\%) であると報告し, Redon ら ${ }^{6)}$ は $0.6 \%$, Kirklin ら ら $^{7}$ は10 例中 5 例 $(0.7$ $\%)$ Eddey ら8) は 138 例中 1 例 $(0.7 \%)$, Ann ら ${ }^{9)}$ は1280例中32例（2.5\%）之報告し, 本邦においては北村ら ${ }^{10)}$ は 306 例中 1 例（0.3 $\%)$, 村上ら ${ }^{11)}$ は70例中 1 例 $(1.4 \%)$, 加納 $ら^{12)}$ は86例中 1 例 $(1.2 \%)$, 杉本ら ${ }^{13)}$ は83例 中 1 例 $(1.2 \%)$ とほぼ $1 \%$ 前後の発生頻度が 記載されている. 我々の施設においては過去 4 年間の耳下腺腫瘍症例 43 例中脂肪腫は本例 1 例 のみであった．男女比に関しては差はないとす る報告, 男性に多いとする報告 ${ }^{9)^{14)}}$ があるが, 我々の涉猟し得た限りでは若干男性に多く, 本 
症例屯男性であった。発生:年齛は30才未満の例 は少なく，多くは30才以上であり，本症例にみ るように，中高年に好発しおり，Ann ら 平均年齢は53才であったと報告している. 症状 は耳下腺部の腫脹のみで, 顔面神経麻瘏, 疼痛 の報告はなく，かなり大きな腫瘍でも開口障害 などは引き起こさないとされる，治療法は他の 耳下腺良性腫瘍之同様, 摘出が選択される. 予 後は良好で, 術後の再発, 高度の顔面神経麻瘏 は報告されていない。

近年耳下腺腫瘍の補助診断法としての各種画

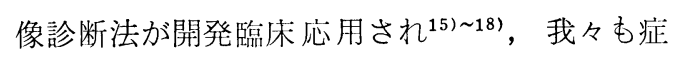
例に応じていくつかの画像診断法を選択して使 用している。本疾患においてその拡がりの面で 充分な情報が得られたのは, CT-sialography であり, これによって, 副咽頭間隙への進展を 術前に知ることができた. CT-sialography は腫揚の副咽頭間隙への拡がりを知るのに極め て有用である ${ }^{19) 20)}$. 村上ら ${ }^{4)}$ はまた, 脂肪腫に おいてはそのCT值を測定することにより，そ の組織が推定可能であるとしている. 脂䏚腫の C T值は一般にー80〜-90であるとされてい

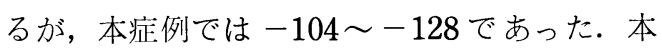
症例におけるごとき低いC T值を呈する脂肪腫 む存在するととより, 脂肪腫の C T值の範囲は 相当に広いととが考えられる，CT像において 腫瘍は極めて均一で一見 cystic な病変を思わ せたが, echography で mixed pattern を 示した事は, cyst を否定する一つの手掛か りになったので耳下腺腫瘍の補助診断として echography の有用性がこの場合屯認識され た. scintigraphy では村上ら ${ }^{4)}$ が脂肪腫は $\mathrm{Ga}$ シンチで陽性所見を示さないとしている が, 本症例では強度の陽性所見を示した。一般 に造影剂注入後約 3 週間までは造影剂の影響を 受けるとされているが, 本症例は造影剂注入後 35日とはいえ，乙の症例でみられた陽性所見は 造影剂汇よる耳下線組織自体の false positive の所見であると考えられる. 耳下腺腫瘍の 診断に当たっては scintigraphy は唾液腺造
影撮影に先だって施行されるべきであり，診断 を進める過程での decision making の重要性 をあらためて痛感する。耳下腺深葉の腫瘍が副 咽頭間隙に伸展するのは稀にみられ，いわゆる 业鈴型耳下腺腫瘍の場合である。野中ら ${ }^{22}$ は， 耳下腺良性腫瘍 47 例中に僅かに 3 例あったと報 告している，乙のように深葉から副咽頭間隙へ 腫瘍が伸展する場合, 前方は下顎骨関節突起, 後方は茎状突起からなる stylomandibular tunnel を通って増大するために，ての部でく びれを生ずるといわれている ${ }^{23)}$.この症例でも 図 6 にみられるように若干くびれた形となって いる，通常副咽頭間隙への拡がりを示す症例で は，咽頭側壁との双指診が有効であるが，本症 例では特記すべき所見は得られなかった。これ は弾性軟を示す脂肪腫の特徵によると考えら れ，双指診に当たってはてのような性質の組織 を念頭において行うべきと考える.

なお耳下腺脂肪腫には耳下腺内に発生するも $の^{3)}$ 之被膜外の耳下腺周囲に発生:するもの ${ }^{4) 91}$ とがある.耳下腺脂䏳腫で本症例の如く深葉に 発生したと明記した報告はなく，本症例は極め て稀なあのであると考えられる。

上記のように本症例は耳下腺深葉に生じた脂 肪腫が副咽頭間隙に伸展していた例であり。特 異な耳下腺腫煌例とみることができる。このた め術前には確実な診断に達することは出来なか ったが，画像診断の上で得られた所見は耳下腺 腫漡の臨床において今後の参考になると思われ る.

\section{まとめ}

耳下腺深葉より発生し, 副咽頭間隙に伸展し た脂肪腫の 1 例（60才男子）を報告した。画像 診断では C T值は脂肪腫の標準值（-80〜90）よりやや低い值（-104〜 - 128）を示し, 唾液腺造影撮影後35日目に行った Ga-scintigraphy の結果でも R I の集積が浔められた. 全麻下に手術を行い䣆鈴型に近い腫瘍を摘出し た. 
本論文の要旨は, 昭和 61 年 6 月 21 日第 217 回日耳鼻 大阪地方連合会で口演した。

\section{参考文献}

1) Di Barlolomeo JR, et al: Pedunculated lipoma of the epiglottis, second know case reported. Arch Otolaryngol $98: 55 \sim 57$, 1973.

2) Knefick TC, et al : Retropharyngeal lipoma. J Laryngol Otol $89:$ 1151 1153, 1975.

3 ) 中村一, 他: 耳下腺脂肪腫の 2 例. 耳鼻臨床 $75: 1653 \sim 1656,1982$.

4) 村上 泰, 他：耳下腺の脂肪腫症を合併した耳 下腺脂肪腫の 1 例. 耳鼻臨床 $79: 949 \sim 954$, 1986.

5) Baker SE, et al : Lipomas of the parotid gland. Oral Surg 52:167 171, 1981.

6) Redon $\mathrm{H}$ and Belcout $\mathrm{J}$ : Enseignemets a retirer dune serie de 455 tumeurs de la region parotidienne. Mem Acad Chir 81:33 $\sim 40,1955$.

7) Kirklin JW, et al : Parotid tumors. Surg Gynecol Obstet $92: 721 \sim 733,1951$.

8 ) Eddey H: Parotid tumors: A review of 138 cases. Aust NZ J Surg 40:1 14, 1970.

9) Walts AE Parzik SL, et al : Lipomatous lesions of the parotid area. Arch Otolaryngol $102: 230 \sim 232,1976$.

10）北村 武, 他: 耳下腺腫演の臨床一教室20年間 の統計的観察一. 耳鼻臨床 $64: 1286 \sim 1301$, 1971.

11）村上 泰, 他：耳下腺腫煌70症例の治療経験。耳 喉 $48: 53 \sim 66,1976$.

12）加納直行, 牧本一男, 他：過去 10 年間における耳
下腺腫演の統計.耳鼻臨床 $75: 1657 \sim 1666$, 1982.

13）杉本嘉朗, 他：耳下腺腫煌の統計的観察一当教 室過去 13 年間の集計一. 耳鼻臨床 $74: 2096$ 2103, 1981.

14) Janecka IP, et al : Lipomas presenting as parotid tumors. Laryngoscope $87: 1007 \sim$ 1011, 1977.

15）浅野 尚：耳下腺腫煬の超音波診断. 耳鼻臨床 $64: 1263 \sim 1270,1971$.

16）山道 至, 他: Xeroradiography の耳鼻咽搌科 領域での応用. 耳鼻臨床 $74 ： 1767 \sim 1773$, 1981.

17）山下敏夫，他：耳下腺部腫場の $\mathrm{C} T$ 診断一適応と 限界一. 日耳鼻 $83: 1627 \sim 1634,1980$.

18）山下敏夫, 他：耳下腺部腫場の総合診断一 R I, $\mathrm{C} T$ ，超音波一。耳鼻臨床 $71 ： 951 \sim 966$, 1978.

19) Stone DN, et al : Parotid CT sialography. Radiology 138:393 397, 1981.

20）卜部信行, 他: 耳下腺部病変の CT-sialography. 耳鼻 $30: 348 \sim 353,1984$.

21）永見徹夫，他：頸部腫留の C T 診断. 耳鼻臨床 $76: 899 \sim 906,1983$.

22）野中信二，他：耳下腺业鈴型混合腫煌の 1 例.耳 鼻臨床 $74: 1587 \sim 1591,1981$.

23) Patey DH, et al: Some points in surgical anatomy of parotid gland. Brit J Surg 45 : 250 258, 1957.

$$
\left.\begin{array}{l}
\text { 原稿採択 : 昭和 } 62 \text { 年 } 6 \text { 月 } 18 \text { 日 } \\
\text { 別刷請求先 : 中島 徹 } \\
\text { T569 高槻市大学町 } 2-7 \\
\text { 大阪医科大学耳鼻咽喉科学教室 }
\end{array}\right)
$$

